\title{
Photobacterium frigidiphilum sp. nov., a psychrophilic, lipolytic bacterium isolated from deep-sea sediments of Edison Seamount
}

Correspondence
Sang-Jin Kim
s-jkim@kordi.re.kr

\author{
Hae Jeom Seo, Seung Seob Bae, Jung-Hyun Lee and Sang-Jin Kim
}

Marine Biotechnology Research Centre, Korea Ocean Research and Development Institute, PO Box 29, Ansan 425-600, Republic of Korea

\begin{abstract}
A Gram-negative, motile, rod-shaped, psychrophilic and weakly halophilic bacterial strain, $\mathrm{SL}_{13}{ }^{\top}$, was isolated from deep-sea sediments (1450 m depth) of Edison Seamount in the western Pacific Ocean. Optimal growth of $S L 13^{\top}$ requires the presence of $1.5 \%(\mathrm{w} / \mathrm{v}) \mathrm{NaCl}$, a pH of $6 \cdot 0$ and a temperature of $14{ }^{\circ} \mathrm{C}$. The whole-cell fatty acid profile of the isolate includes $\mathrm{C} 16: 1$ and $\mathrm{C} 16: 0$ as major fatty acids and contains $\mathrm{C} 20: 5 \omega 3$. This is consistent with corresponding data for Photobacterium profundum. The DNA G $+C$ content of strain $\mathrm{SL}_{13}{ }^{\top}$ is $43.8 \mathrm{~mol} \%$. Phylogenetic analyses of $16 \mathrm{~S}$ rRNA gene sequences place this bacterium in the 'Gammaproteobacteria', within the genus Photobacterium. Sequence similarity analysis indicates that the closest relatives of strain $\mathrm{SL}_{13}{ }^{\top}$ are Photobacterium indicum (99.3\%), P. profundum $(98.5 \%)$ and Photobacterium lipolyticum (98.2\%). The DNA-DNA hybridization levels between the isolate and its closest known phylogenetic relatives, $P$. indicum, $P$. profundum and $P$. lipolyticum, are 27·1, 52.4 and $20.2 \%$, respectively. Thus strain SL13 ${ }^{\top}$ represents a novel species of the genus Photobacterium, for which the name Photobacterium frigidiphilum sp. nov. is proposed. The type strain is $\mathrm{SL}_{13}{ }^{\top}\left(=\mathrm{KCTC} 12384^{\top}=\mathrm{JCM} 12947^{\top}\right)$.
\end{abstract}

In terms of taxonomic identification, historically there has been some confusion between the bacterial genera Photobacterium and Vibrio. The genus Photobacterium comprises a group of Gram-negative, facultatively anaerobic, plump and straight rod-shaped bacteria that require sodium ions for growth. These species can accumulate poly- $\beta$ hydroxybutyrate under certain culture conditions, and do not utilize exogenous monomers of $\beta$-hydroxybutyrate. Unlike the flagella of Vibrio species, which are also common in marine environments, the flagella of all Photobacterium species lack an enclosing sheath (Baumann \& Baumann, 1984). Vibrio iliopiscarius was proposed as a species of the genus Vibrio because it has sheathed flagella and because poly- $\beta$-hydroxybutyrate was not found in this strain (Onarheim et al., 1994). However, this strain was later reclassified as Photobacterium iliopiscarium comb. nov. on the basis of phylogenetic analysis of $16 \mathrm{~S}$ rRNA gene sequences and restriction fragment length polymorphism

Published online ahead of print on 14 March 2005 as DOI 10.1099/ ijs.0.63338-0.

The GenBank/EMBL/DDBJ accession number for the $16 \mathrm{~S}$ rRNA gene sequence of strain $S L 13^{\top}$ is $A Y 538749$.

A table of physiological properties of strain $S L 13^{\top}$ and a graph showing growth of the strain under varying barometric pressure are available as supplementary material in IJSEM Online. patterns of 16S rRNA gene sequences digested with HhaI, which differ from those observed in other species of the genus Vibrio (Urakawa et al., 1998, 1999).

Species of the genus Photobacterium, which belongs to the family Vibrionaceae together with the genera Vibrio and Listonella, are widespread in marine environments (Baumann \& Baumann, 1984; Okuzumi et al., 1994; Shieh et al., 2003). Photobacterium phosphoreum was first reported in 1889; at present, there are nine known species. $P$. phosphoreum, Photobacterium leiognathi and Photobacterium profundum were isolated from sea water, the intestinal contents of marine animals, and deep-sea sediment, respectively (Baumann \& Baumann, 1984; Nogi et al., 1998). Typically, marine environments have low temperatures; consequently, psychrophiles, whose optimum growth temperature is lower than $20^{\circ} \mathrm{C}$, are abundant in marine environments. $P$. iliopiscarium, $P$. phosphoreum, $P$. profun$d u m$ and several other species of the genus Photobacterium are psychrophilic. Of these, $P$. profundum was the first to be reported from the deep sea, after being isolated from the sediments of the Ryukyu Trench (5110 m deep; Nogi et al., 1998).

Here, we describe the morphological, phenotypic, phylogenetic and genomic characteristics of strain SL13 ${ }^{\mathrm{T}}$ isolated from deep-sea sediment samples. On the basis of this polyphasic evidence, we propose that $\mathrm{SL}_{1} 3^{\mathrm{T}}$ be assigned as a 
novel species of the genus Photobacterium, for which the name Photobacterium frigidiphilum sp. nov. is proposed.

Sediment samples were collected at Edison Seamount (cold seep area at $1500 \mathrm{~m}$ depth) using a video-guided grab sampler (TV-Grab; Preuss). Edison Seamount is positioned south of Lihir Island, Papua New Guinea, in the Western Pacific Ocean. Immediately after sampling, $\sim 0 \cdot 3 \mathrm{~g}$ chilled deep-sea sediment was ground in a mortar and inoculated into $30 \mathrm{ml}$ of autoclaved marine broth 2216 (MB; Difco) containing $1 \%(\mathrm{v} / \mathrm{v})$ hexadecane in a $100 \mathrm{ml}$ Erlenmeyer flask. After incubation at $10^{\circ} \mathrm{C}$ for 7 days on an orbital shaker (JEIO TECH; 120 r.p.m.), $150 \mu$ l culture broth was spread onto plates of marine agar 2216 (MA; Difco) supplemented with $1 \%(\mathrm{v} / \mathrm{v})$ tributyrin. The plates were then incubated at $10{ }^{\circ} \mathrm{C}$ for 7 days. Individual colonies with halo zones were isolated from the tributyrin plates. This process was repeated on MA until pure cultures were obtained.

Air-dried smears from MA cultures were stained using the Difco Gram-staining kit, according to the manufacturer's instructions. Cell morphology and flagellum type were examined by transmission electron microscopy (model FDL5000; JEOL). Cells grown for 3 days at $10^{\circ} \mathrm{C}$ on MA were negatively stained with $1 \%(\mathrm{w} / \mathrm{v})$ phosphotungstic acid. After being air-dried, the grids were examined by transmission electron microscopy at $12000 \times$ magnification.

Biochemical tests were performed using API 20NE (bioMérieux) according to the manufacturer's instructions, but with a modified saline solution (containing, $\mathrm{I}^{-1}$ distilled water, $8 \cdot 8 \mathrm{~g} \mathrm{MgCl}_{2} \cdot 6 \mathrm{H}_{2} \mathrm{O}, 1 \cdot 8 \mathrm{~g} \mathrm{CaCl}_{2} \cdot 2 \mathrm{H}_{2} \mathrm{O}$ and $20 \mathrm{~g}$ $\mathrm{NaCl}$ ) instead of the API 20NE saline solution for bacterial suspension (Sohn et al., 2004a). The cells' ability to utilize different carbon sources were examined using a Biolog GN2 MicroPlate, for which the bacterial suspensions were prepared as described above. Catalase activity was determined by means of bubble production in a $3 \%(\mathrm{v} / \mathrm{v})$ hydrogen peroxide solution, and lipase activity was assessed by observing the formation of clear zones around colonies on MA containing $1 \%(\mathrm{v} / \mathrm{v})$ tributyrin. Growth potential under anaerobic conditions was tested as described by Sohn et al. (2004b), and the presence of oxygen was monitored using resazurin as an indicator of redox potential. Luminescence was checked, in darkness, after 2 days incubation at $10{ }^{\circ} \mathrm{C}$ in $\mathrm{MB}$. Susceptibility to the vibriostatic agent 2,4-diamino-6,7-diisopropylpteridine (O/129; Sigma) was determined by the disc-diffusion method using 10 and $150 \mu \mathrm{g} \mathrm{O} / 129$ (Donovan \& Furniss, 1984).

Growth characteristics were examined using $\mathrm{MB}$ as a basal medium. To determine the optimal temperature for growth, the growth rates were calculated from optical density values measured in a temperature-gradient incubator (TVS126MA; Advantec). To determine the optimal $\mathrm{pH}$ for growth, $\mathrm{MB}$ was dissolved in the following buffers (Sigma) at a concentration of $20 \mathrm{mM}$ : for $\mathrm{pH} 4,5$ and $5 \cdot 5$, MES buffer; for $\mathrm{pH} 6$ and 6.5, PIPES buffer; for $\mathrm{pH} 7$ and
7·5, HEPES buffer; and for $\mathrm{pH} 8,9$ and 10, AMPSO buffer (Bae et al., 2005). The requirement for $\mathrm{NaCl}$ was tested using modified $\mathrm{MB}$, containing (per litre distilled water) $5 \mathrm{~g}$ bactopeptone, 1 g yeast extract and $0.01 \mathrm{~g} \mathrm{FePO}_{4} \cdot 4 \mathrm{H}_{2} \mathrm{O}$, supplemented with different $\mathrm{NaCl}$ concentrations. The requirements for $\mathrm{MgCl}_{2}$ and/or $\mathrm{CaCl}_{2}$ were determined using modified $\mathrm{MB}$ containing $2 \%(\mathrm{w} / \mathrm{v}) \mathrm{NaCl}$ along with $8.8 \mathrm{~g} \mathrm{MgCl}_{2} \mathrm{l}^{-1}$ and/or $1.8 \mathrm{~g} \mathrm{CaCl}_{2} \mathrm{l}^{-1}$.

Strain $\mathrm{SL} 13^{\mathrm{T}}$ was Gram-negative, rod-shaped, motile by means of a single polar flagellum and approximately $0 \cdot 8$ $1.5 \mu \mathrm{m}$ in width by $2 \cdot 3-3 \cdot 8 \mu \mathrm{m}$ in length (Fig. 1 ). Colonies on MA (after incubation for 3 days at $10^{\circ} \mathrm{C}$ ) were creamcoloured, opaque, smooth, circular, convex with entire margins and $2 \cdot 0-3 \cdot 0 \mathrm{~mm}$ in diameter. Luminescence was not observed. The isolate was susceptible to O/129. Strain $\mathrm{SL} 13^{\mathrm{T}}$ grew optimally at $14{ }^{\circ} \mathrm{C}$ and growth was possible between 6 and $20^{\circ} \mathrm{C}$ (Fig. 2). SL13 ${ }^{\mathrm{T}}$ did not grow at temperatures higher than $20^{\circ} \mathrm{C}$. The strain grew at rates greater than half-optimal at $6^{\circ} \mathrm{C}$. It grew well within the $\mathrm{pH}$ range $5 \cdot 0-8 \cdot 5$ and optimally at pH $6 \cdot 0$. Optimal growth for $\mathrm{SL}_{1} 3^{\mathrm{T}}$ occurred in the presence of $1.5 \%(\mathrm{w} / \mathrm{v}) \mathrm{NaCl}$; no growth occurred at $\mathrm{NaCl}$ concentrations above $4.0 \%$ or in the absence of $\mathrm{NaCl}$. In addition, $\mathrm{SL} 13^{\mathrm{T}}$ required either $\mathrm{MgCl}_{2}$ or $\mathrm{CaCl}_{2}$ for growth. The isolate showed catalase, oxidase, arginine dihydrolase, $\beta$-glucosidase, protease and lipase activities, but no urease activity. Nitrate was reduced to nitrite, and indole was produced. As the strain was unable to grow in AUX medium (from the API 20NE test kit), no data were obtained with respect to $12 \mathrm{C}$ assimilation. On the basis of Biolog tests, strain $\mathrm{SL}_{1}{ }^{\mathrm{T}}$ could oxidize the

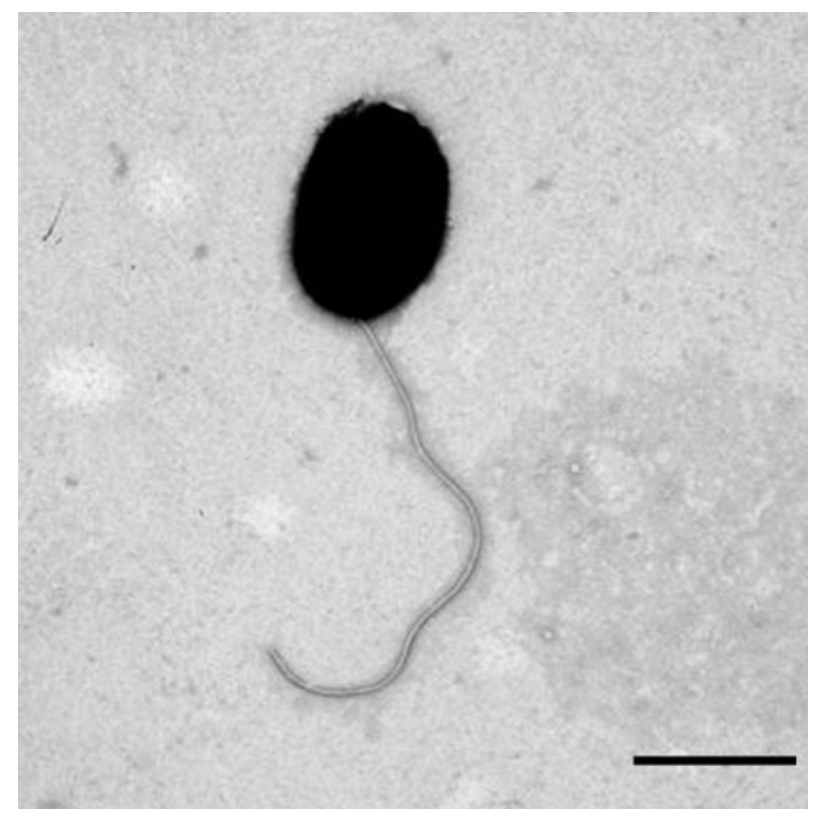

Fig. 1. Transmission electron micrograph of a negatively stained cell of strain $\mathrm{SL}_{13}{ }^{\top}$. Bar, $1 \mu \mathrm{m}$. 


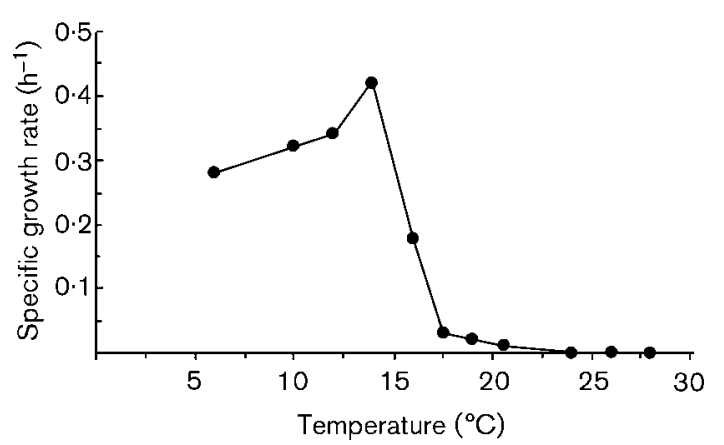

Fig. 2. Temperature-dependent growth of $S L 13^{\top}$.

various carbon compounds listed in the species description. The physiological characteristics of strain $\mathrm{SL} 13^{\mathrm{T}}$ are listed in a supplementary table available in IJSEM Online. On the basis of those phenotypes, $\mathrm{SL}_{13}{ }^{\mathrm{T}}$ can be differentiated from related Photobacterium type strains (Table 1).

To determine the response of cell growth under pressure, the $\mathrm{OD}_{660}$ was measured every 2 or $3 \mathrm{~h}$ during incubation at $14^{\circ} \mathrm{C}$ in $\mathrm{MB}$ under pressure (from $0 \cdot 1$ to $50 \mathrm{MPa}$ ). Strain $\mathrm{SL} 13^{\mathrm{T}}$ was found to be slightly piezophilic: the optimum pressure for growth was $10 \mathrm{MPa}$ (see the supplementary figure available in IJSEM Online). However, this strain could be piezosensitive, as there was no growth under high hydrostatic pressure (50 MPa).

The total lipid component of cells incubated at $10^{\circ} \mathrm{C}$ for 3 days was extracted using the method of Folch et al. (1957). For the analysis of fatty acid composition, total lipids were converted to fatty acid methyl esters by serial addition of $1.5 \%(\mathrm{w} / \mathrm{v}) \mathrm{NaOH}$ and $5 \%(\mathrm{v} / \mathrm{v}) \mathrm{HCl}$ in methanol; both reactions were repeated at $65^{\circ} \mathrm{C}$ for $20 \mathrm{~min}$. Fatty acid methyl esters were analysed with a gas chromatograph (5890II; Hewlett Packard) equipped with a flame-ionization detector and a capillary column (non-polar SPB-1; $25 \mathrm{~m} \times$ $0.25 \mathrm{~mm}$ ). Bacterial fatty acid methyl ester standards (Supelco) and equivalent chain-length values (Stransky et al., 1992) were used for fatty acid identification. The DNA $\mathrm{G}+\mathrm{C}$ content $(\mathrm{mol} \%)$ of the isolate was determined by the melting temperature method, as described by Sohn et al. (2004b). Purified chromosomal DNA extracted from Escherichia coli K-12 (= KCTC 2443) served as a control.

Table 1. Physiological characteristics that differentiate strain $\mathrm{SL}_{1}{ }^{\top}$ from related Photobacterium type species

Strains: 1, SL13 ${ }^{\mathrm{T}} ; 2$, P. indicum NBRC $14233^{\mathrm{T}}$ (data from Xie \& Yokota, 2004); 3, P. profundum JCM 10084 ${ }^{\mathrm{T}}$ (Nogi et al., 1998); 4, P. lipolyticum KCTC $10562^{\mathrm{T}}$ (Yoon et al., 2005); 5, Photobacterium angustum ATCC 25915 ${ }^{\mathrm{T}}$ (Nogi et al., 1998); 6, P. phosphoreum ATCC 11040 (Nogi et al., 1998); 7, Photobacterium damselae subsp. damselae JCM 8968 ${ }^{\mathrm{T}}$ (Okuzumi et al., 1994); 8, P. leiognathi ATCC 25521 ${ }^{\mathrm{T}}$ (Nogi et al., 1998). Symbols: +, positive; -, negative; ND, not determined. All strains were positive for utilization of $\alpha$-D-glucose. All strains were negative for Gram stain, nitrite reduction to nitrogen and utilization of L-arabinose and $\alpha$-D-lactose.

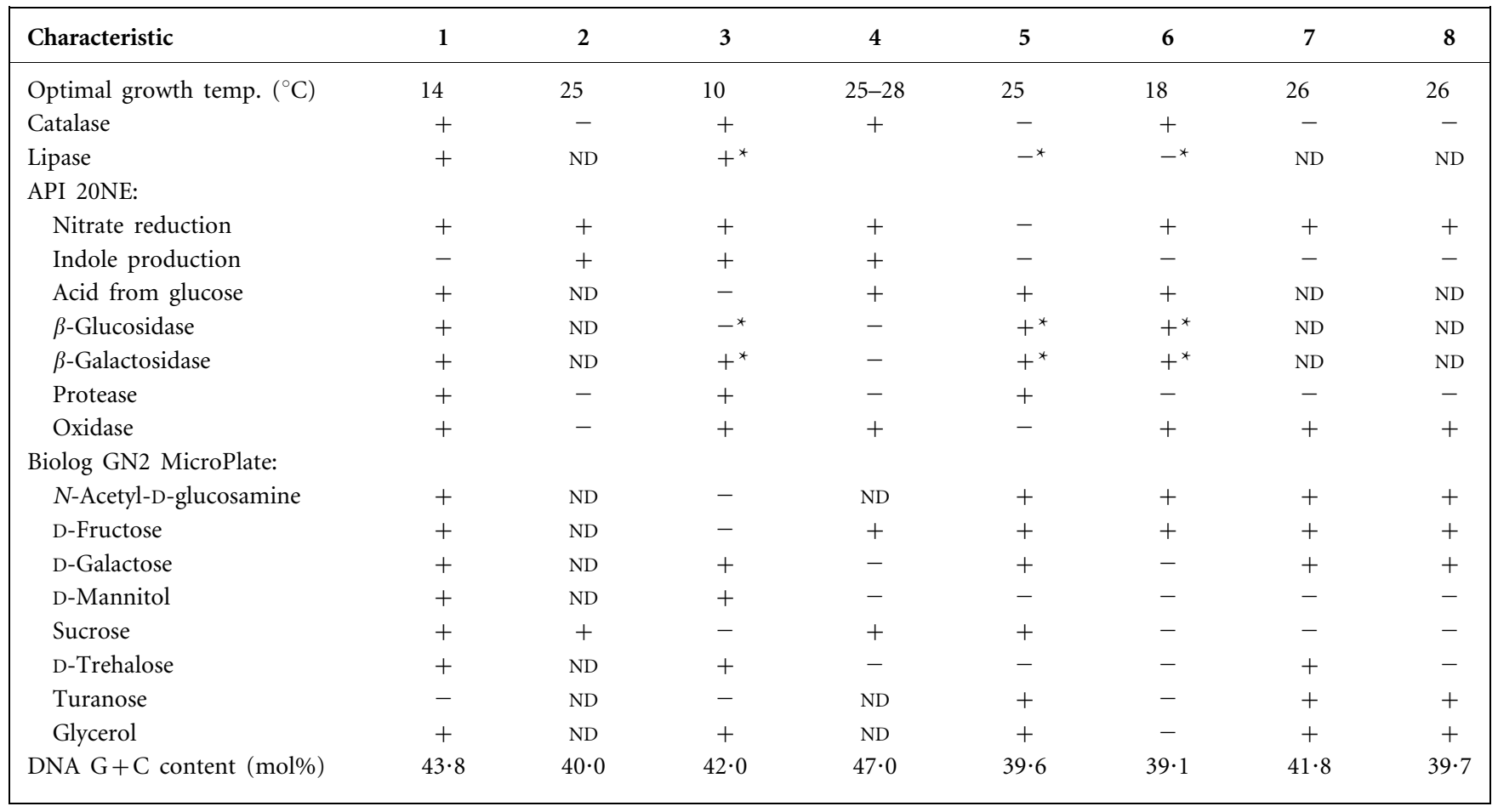

${ }^{\star}$ Determined in the present study. 
Table 2. Cellular fatty acid compositions of strain $S L 13^{\top}$ and related Photobacterium species

Strains: 1, SL13 ${ }^{\mathrm{T}} ; 2$, P. indicum NBRC $14233^{\mathrm{T}}$ (data from Nogi et al., 1998; Xie \& Yokota, 2004); 3, P. profundum JCM $10084^{\mathrm{T}}$ (Nogi et al., 1998; Xie \& Yokota, 2004); 4, P. lipolyticum KCTC $10562^{\mathrm{T}}$ (Yoon et al., 2005); 5, P. phosphoreum ATCC $11040^{\mathrm{T}}$ (Nogi et al., 1998; Xie \& Yokota, 2004). Values are percentages of total fatty acids.

\begin{tabular}{|lccccc|}
\hline Fatty acid & $\mathbf{1}$ & $\mathbf{2}$ & $\mathbf{3}$ & $\mathbf{4}$ & $\mathbf{5}$ \\
\hline $12: 0$ & 5 & 4 & 2 & - & 6 \\
$13: 0$ & 2 & - & - & - & - \\
$3-\mathrm{OH} 12: 0$ & - & 2 & 5 & 4 & 9 \\
iso- $13: 0$ & - & - & 2 & - & - \\
iso- $14: 0$ & - & - & 4 & - & - \\
$14: 0$ & 5 & 7 & 3 & $3 \cdot 8$ & 11 \\
$14: 1$ & - & 1 & 3 & - & 1 \\
$3-\mathrm{OH} 14: 0$ & - & - & - & - & 3 \\
iso- $15: 0$ & - & 1 & 2 & - & - \\
$15: 1$ & - & - & - & - & - \\
$15: 0$ & - & 2 & 1 & - & - \\
iso- $16: 0$ & 1 & 1 & 15 & - & - \\
$16: 1$ & 37 & 41 & 32 & - & 40 \\
$16: 1 \omega 7^{*}$ & - & - & - & $51 \cdot 3$ & - \\
$16: 0$ & 23 & 26 & 9 & $25 \cdot 9$ & 25 \\
$17: 1$ & - & - & - & - & - \\
iso- $17: 0$ & 1 & 1 & - & - & - \\
cyc- $17: 0$ & 1 & - & - & - & - \\
$17: 0$ & - & 1 & - & - & - \\
$18: 1$ & 12 & 3 & 9 & - & 3 \\
$18: 1 \omega 7 c$ & - & - & - & $5 \cdot 9$ & - \\
$18: 0$ & 3 & 1 & 1 & - & 1 \\
$20: 5 \omega 3$ & 6 & - & 13 & - & - \\
\hline$\times$ And & & & & & \\
\hline
\end{tabular}

${ }^{*}$ And/or $2-\mathrm{OH}$ iso- $15: 0$.

The cellular fatty acids ranged in size from C12 to C20 and included saturated, monoenoic and iso-branched components (Table 2). The major fatty acids in the strain were $\mathrm{C} 12: 0, \mathrm{C} 14: 0, \mathrm{C} 16: 1, \mathrm{C} 16: 0, \mathrm{C} 18: 1$ and $\mathrm{C} 20: 5 \omega 3$, a range similar to that reported for other Photobacterium species (Nogi et al., 1998). Of particular note among the fatty acids of $\mathrm{SL}^{2} 3^{\mathrm{T}}$ was $20: 5 \omega 3$, which is usually found in both psychrophilic and piezophilic marine bacteria (DeLong et al., 1997; Nogi et al., 1998). The fatty acid composition of $\mathrm{SL}_{1} 3^{\mathrm{T}}$ is similar to that reported for $P$. profundum JCM $10084^{\mathrm{T}}$ isolated from the deep sea (Nogi et al., 1998). The DNA G + C content of strain $\mathrm{SL}_{13}{ }^{\mathrm{T}}$ was $43.8 \mathrm{~mol} \%$, which is within the range (40-44 mol\%) for the genus Photobacterium (Baumann \& Baumann, 1984).

Genomic DNA was extracted from MB-cultured SL13 ${ }^{\mathrm{T}}$ using the Wizard genomic DNA purification kit (Promega). The 16S rRNA gene sequence was amplified from genomic DNA by using a PCR with the universal primers $27 \mathrm{~F}$ and 1522R (Weisburg et al., 1991). The PCR product was sequenced using an ABI Prism 3100 Genetic Analyzer (Applied Biosystems) and the resultant 16S rRNA gene sequences were manually aligned with those from other Photobacterium species and related taxa, using known 16S rRNA secondary-structure information. Phylogenetic trees were constructed using neighbour-joining (Saitou \& Nei, 1987), Fitch-Margoliash (Fitch \& Margoliash, 1967), maximum-likelihood (Felsenstein, 1993) and maximumparsimony (Fitch, 1972) methods. Evolutionary distance matrices (for the neighbour-joining and Fitch-Margoliash methods) were generated according to the Jukes-Cantor model (Jukes \& Cantor, 1969). The trees were rooted using E. coli (GenBank accession no. X80725) as an outgroup. The PHYLIP software package (Felsenstein, 1993) was used for all phylogenetic analyses. The resultant unrooted tree topology was evaluated by bootstrap analysis (1000 replicates; Felsenstein, 1985) of the neighbour-joining tree.

The 16S rRNA gene sequence of SL13 ${ }^{\mathrm{T}}$ obtained in this study consisted of $1536 \mathrm{nt}$. In terms of $16 \mathrm{~S}$ rRNA gene sequence similarity, the closest relatives of strain SL13 ${ }^{\mathrm{T}}$ were Photobacterium indicum $(99 \cdot 3 \%), P$. profundum (98.5\%), Photobacterium lipolyticum (98.2\%), P. iliopiscarium (97.4\%) and P. phosphoreum (97.2\%). Lower sequence similarities $(<97 \cdot 0 \%)$ were found with all other Photobacterium species with validly published names (Fig. 3).

DNA-DNA hybridization was performed according to the method of De Ley et al. (1970). The resultant estimates of DNA relatedness between the isolate and the three type strains of the most closely related Photobacterium species ( $P$. indicum, $P$. profundum and $P$. lipolyticum) were less than $53 \%$ (Table 3), which is significantly lower than that accepted as the phylogenetic definition of a species (Wayne et al., 1987).

\section{Description of Photobacterium frigidiphilum sp. nov.}

Photobacterium frigidiphilum (fri.gi.di.phi'lum. L. adj. frigidus cold; N.L. adj. philus -a -um from Gr. adj. philos friendly to, loving; N.L. neut. adj. frigidiphilum cold-loving).

Cells are rod-shaped, $0 \cdot 8-1 \cdot 5 \mu \mathrm{m}$ in width and $2 \cdot 3-3 \cdot 8 \mu \mathrm{m}$ in length, motile by means of a polar flagellum and Gramnegative. Colonies are cream-coloured, opaque, smooth, circular, convex, with entire margins, and form on MA at $10{ }^{\circ} \mathrm{C}$ after 3 days. Non-luminescent. Susceptible to O/ 129. Facultatively anaerobic. Psychrophilic. Growth occurs between 6 and $20^{\circ} \mathrm{C}$, with an optimum at $14^{\circ} \mathrm{C}$. The $\mathrm{pH}$ range for growth is $5 \cdot 0-8 \cdot 5$, with an optimum at $\mathrm{pH} 6 \cdot 0$. Has an absolute requirement for $\mathrm{NaCl}$ for growth; growth occurs at $\mathrm{NaCl}$ concentrations of $1 \cdot 0-3 \cdot 5 \%(\mathrm{w} / \mathrm{v})$ and is optimal at $1.5 \%(\mathrm{w} / \mathrm{v})$. Catalase, oxidase, arginine dihydrolase, $\beta$-glucosidase, protease, $\beta$-galactosidase and lipase are present. Reduction of nitrate to nitrite occurs, and indoles are produced. Does not utilize $\beta$-hydroxybutyrate. The following carbon sources are utilized: dextrin, glycogen, Tweens 40 and $80, \mathrm{D}$-fructose, $\mathrm{N}$-acetyl-D-glucosamine, 


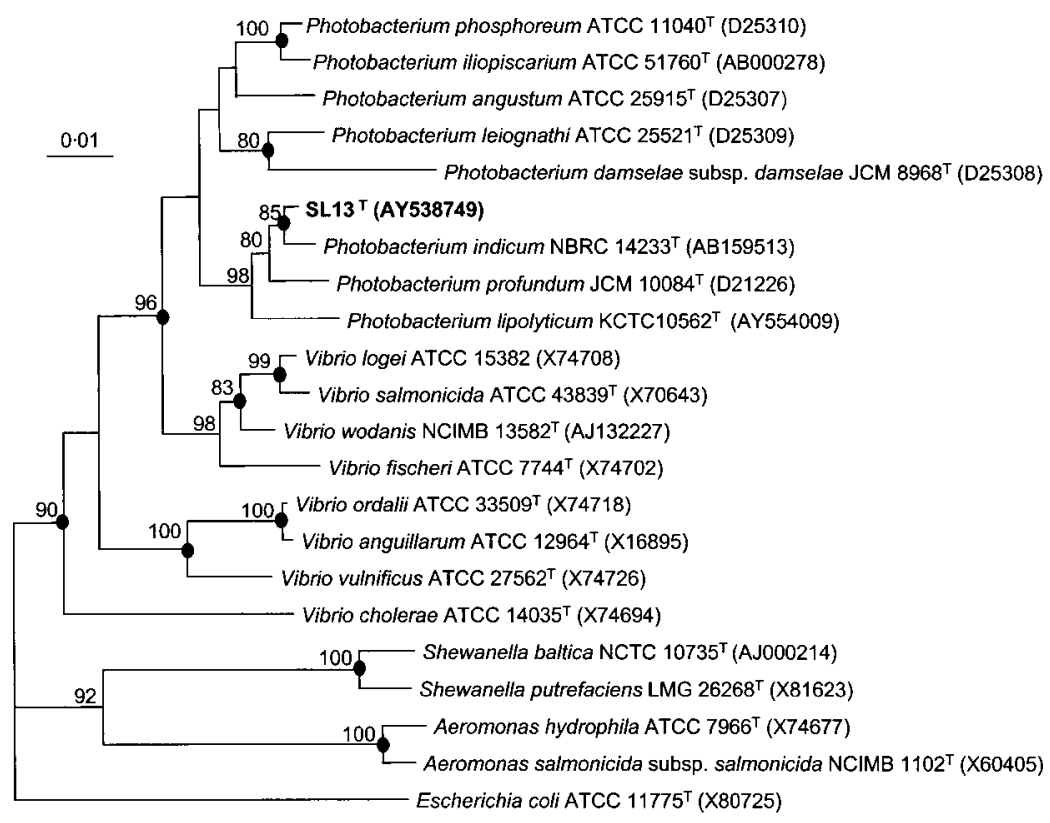

Fig. 3. Neighbour-joining tree showing the phylogenetic positions of strain $\mathrm{SL}_{1}{ }^{\top}$ and related taxa based on 16S rRNA gene sequences. Numbers at nodes are levels of bootstrap support (\%) based on neighbourjoining analyses of 1000 resampled datasets; only values above $70 \%$ are given. Filled circles indicate clades that were also supported by the Fitch-Margoliash, maximum-parsimony and maximum-likelihood trees. Bar, 0.01 substitutions per nucleotide position.

$N$-acetyl-D-galactosamine, D-fructose, D-galactose, $\alpha$-Dglucose, myo-inositol, maltose, D-mannitol, D-mannose, sucrose, D-trehalose, D-glucuronic acid, DL-lactic acid, propionic acid, succinic acid, D-alanine, L-alanine, Lasparagine, L-aspartic acid, L-glutamic acid, glycyl-Laspartic acid, glycyl-L-glutamic acid, L-serine, inosine, glycerol and D-glucose-6-phosphate. The major fatty acids are oleic acid (C16:1) and palmitic acid (C16:0); the fatty acid profiles contain eicosapentaenoic acid (C20:5 53 ). The DNA G $+\mathrm{C}$ content is $43 \cdot 8 \mathrm{~mol} \%$.

The type strain, SL13 ${ }^{\mathrm{T}}\left(=\mathrm{KCTC} 12384^{\mathrm{T}}=\mathrm{JCM} 12947^{\mathrm{T}}\right)$, was isolated from sediments at Edison Seamount $(1500 \mathrm{~m}$ depth) in the western Pacific Ocean.

\section{Acknowledgements}

We thank the Chief Scientist of the German cruise SONNE-166 (2002), Dr P. M. Herzig, Dr S.-M. Lee and the Captain and crew of the RV Sonne. We also thank Professor H. G. Trüper, Dr C. Kato and Dr Y. H. Lee for nomenclatural assistance, the pressure experiment and manuscript correction, respectively. This work was supported by the Marine and Extreme Genome Research Center Program and the Marine Novel Bioactive Development Program, Ministry of Maritime Affairs and Fisheries, the 21C Frontier Microbial Genomics and Applications Center Program, Ministry of Science and Technology

Table 3. Levels of DNA reassociation between $\mathrm{SL}_{13}{ }^{\top}$ and related Photobacterium type strains

\begin{tabular}{|lc|}
\hline Source of unlabelled DNA & $\begin{array}{c}\text { Reassociation (\%) with } \\
\text { labelled DNA from SL13 }\end{array}$ \\
\hline P. indicum NBRC $14233^{\mathrm{T}}$ & $27 \cdot 1$ \\
P. profundum JCM $10084^{\mathrm{T}}$ & $52 \cdot 4$ \\
P. lipolyticum KCTC $10562^{\mathrm{T}}$ & $20 \cdot 2$ \\
\hline
\end{tabular}

(grant MG 02-0101-001-1-0-0) and in-house project PE91900 of the Korea Ocean Research and Development Institute, Republic of Korea.

\section{References}

Bae, S. S., Lee, J.-H. \& Kim, S.-J. (2005). Bacillus alveayuensis sp. nov., a thermophilic bacterium isolated from deep-sea sediments of Ayu Trough. Int J Syst Evol Microbiol 55, 1211-1215.

Baumann, P. \& Baumann, L. (1984). Genus II. Photobacterium Beijerinck 1889, 401 ${ }^{\mathrm{AL}}$. In Bergey's Manual of Systematic Bacteriology, vol. 1, pp. 539-545. Edited by N. R. Krieg \& J. G. Holt. Baltimore: Williams \& Wilkins.

De Ley, J., Cattoir, H. \& Reynaerts, A. (1970). The quantitative measurement of DNA hybridization from renaturation rates. Eur J Biochem 12, 133-142.

DeLong, E. F., Franks, D. G. \& Yayanos, A. A. (1997). Evolutionary relationships of cultivated psychrophilic and barophilic deep-sea bacteria. Appl Environ Microbiol 63, 2105-2108.

Donovan, T. J. \& Furniss, A. L. (1984). Vibrios, aeromonas, plesiomonas and photobacterium. In Microbiological Methods, pp. 271279. Edited by C. H. Collins \& P. M. Lyne. London: Butterworth.

Felsenstein, J. (1985). Confidence limits on phylogenies: an approach using the bootstrap. Evolution 39, 783-791.

Felsenstein, J. (1993). PHYLIP - Phylogeny Inference Package, version 3.5c. Distributed by the author. Department of Genome Sciences, University of Washington, Seattle, USA.

Fitch, W. M. (1972). Towards defining the course of evolution: minimum change for a specific tree topology. Syst Zool 20, 406-416.

Fitch, W. M. \& Margoliash, E. (1967). Construction of phylogenetic trees. Science 155, 279-284.

Folch, J., Lees, M. \& Sloane Stanley, G. H. (1957). A simple method for the isolation and purification of total lipids from animal tissues. J Biol Chem 226, 497-509.

Jukes, T. H. \& Cantor, C. R. (1969). Evolution of protein molecules. In Mammalian Protein Metabolism, vol. 3, pp. 21-132. Edited by H. N. Munro. New York: Academic Press. 
Nogi, Y., Masui, N. \& Kato, C. (1998). Photobacterium profundum sp. nov., a new, moderately barophilic bacterial species isolated from a deep-sea sediment. Extremophiles 2, 1-7.

Okuzumi, M., Hiraishi, A., Kobayashi, T. \& Fuhii, T. (1994). Photobacterium histaminum sp. nov., a histamine-producing marine bacterium. Int J Syst Bacteriol 44, 631-636.

Onarheim, A. M., Wiik, R., Burghardt, J. \& Stackebrandt, E. (1994). Characterization and identification of two Vibrio species indigenous to the intestine of fish in cold sea water; description of Vibrio iliopiscarius sp. nov. Syst Appl Microbiol 17, 370-379.

Saitou, N. \& Nei, M. (1987). The neighbor-joining method: a new method for reconstructing phylogenetic trees. Mol Biol Evol 4, 406-425.

Shieh, W. Y., Chen, Y.-W., Chaw, S.-M. \& Chiu, H.-H. (2003). Vibrio ruber sp. nov., a red, facultatively anaerobic, marine bacterium isolated from sea water. Int J Syst Evol Microbiol 53, 479-484.

Sohn, J. H., Lee, J. H., Yi, H., Chun, J., Bae, K. S., Ahn, T.-Y. \& Kim, S.-J. (2004a). Kordia algicida gen. nov., sp. nov., an algicidal bacterium isolated from red tide. Int J Syst Evol Microbiol 54, 675-680.

Sohn, J. H., Kwon, K. K., Kang, J. H., Jung, H.-B. \& Kim, S.-J. (2004b). Novosphingobium pentaromativorans sp. nov., a highmolecular-mass polycyclic aromatic hydrocarbon-degrading bacterium isolated from estuarine sediment. Int J Syst Evol Microbiol 54, $1483-1487$.
Stransky, K., Jursik, T., Vitek, A. \& Skorepa, J. (1992). An improved method of characterizing fatty acids by equivalent chain length values. J High Resolut Chromatogr 15, 730-740.

Urakawa, H., Kita-Tsukamoto, K. \& Ohwada, K. (1998). A new approach to separate the genus Photobacterium from Vibrio with RFLP patterns by HhaI digestion of PCR-amplified 16S rDNA. Curr Microbiol 36, 171-174.

Urakawa, H., Kita-Tsukamoto, K. \& Ohwada, K. (1999). Reassessment of the taxonomic position of Vibrio iliopiscarius (Onarheim et al. 1994) and proposal for Photobacterium iliopiscarium comb. nov. Int J Syst Bacteriol 49, 257-260.

Wayne, L. G., Brenner, D. J., Colwell, R. R. \& 9 other authors (1987). International Committee on Systematic Bacteriology. Report of the ad hoc committee on reconciliation of approaches of bacterial systematics. Int J Syst Bacteriol 37, 463-464.

Weisburg, W. G., Barns, S. M., Pelletier, D. A. \& Lane, D. J. (1991) $16 \mathrm{~S}$ ribosomal DNA amplification for phylogenetic study. J Bacteriol 173, 697-703.

Xie, C.-H. \& Yokota, A. (2004). Transfer of Hyphomicrobium indicum to the genus Photobacterium as Photobacterium indicum comb. nov. Int J Syst Evol Microbiol 54, 2113-2116.

Yoon, J.-H., Lee, J.-K., Kim, Y.-O. \& Oh, T. K. (2005). Photobacterium lipolyticum sp. nov., a bacterium with lipolytic activity isolated from the Yellow Sea in Korea. Int J Syst Evol Microbiol 55, 335-339. 